\title{
Research on Control Measures and Problems of Investment Control of Construction Project
}

\author{
Liu Yan \\ WeiFang University of Science \& Technology \\ ShouGuang, 262700, China; \\ E-mail:sgly2006@126.com
}

\begin{abstract}
This paper describes how to effectively control the project investment,we give a comprehensive exposition of how to effectively control the project investment from the project decision-making stage, project design stage, project bidding phase, the construction phase of the project respectively, emphasizing the importance of the investment control in each stage, and analysis the role of the control in each stage in the whole process of project. To find out the problems easy to appear and make the strategy, methods and measures,take a good grasp of investment control, reduce the loss of investment in each stage, so as to improve the project investment benefit.
\end{abstract}

Keywords-Engineering projects; Investment; Dynamic control

\section{INTRODUCTION}

With a total investment of construction projects, generally relates to the total cost of the project construction cost on a project. Productive total investment for construction projects includes construction investment and circulating capital of two parts; Non-productive construction project total investment is only including construction investment. The construction investment, the equipment and instrument purchase expense, construction and installation engineering, other engineering construction cost, reserve funds (including basic reserve funds and increase reserve funds), construction of interest and fixed assets investment adjustment tax (now temporarily not to collect). Project investment control is in has no impact on the project progress, project quality, safety, construction conditions, the project of the actual cost control within the target value. The control targets as the baseline, the implementation in the whole project management process.

\section{THE PROBLEMS EXISTING IN THE}

CONSTRUCTION PROJECT INVESTMENT CONTROL

Construction project including buildings and structures of the building, rebuilding, the relocation, resume, etc. It is a costly and long construction period, large work risk characteristics. The reasons mainly include the following:

1)Ignore prior to the construction of the project investment control, heavy construction stage, according to the figure to calculate volume, pricing.

2)Design must rely on professional design institute, or institutions outside the design completed. The design time is short and heavy task.

3)In the process of the construction investment control is not strict, additional cost happens very often.

\section{CONSTRUCTION PROJECTINVESTMENT CONTROL COUNTERMEASURES}

\section{A. Planned construction entire process of} investment control, with emphasis on the design stage.

Prior to the construction of the project is the most important stage affect the engineering investment, also is one of the largest stages possible to reduce costs. To effectively control investment, we must do, with emphasis on the construction project planning and design stage, the whole process of investment control, should pay particular attention to the following link for this job. Accurate calculation, reasonable prices and make pre-tender estimate. By bill of 
quantities in bidding quotation, implements the separation of quantity and price, optimizing project contracting units, make a success of the bidding. From project planning, design, construction to completion inspection and acceptance, the whole process of people, goods, content and comprehensive scientific management.

\section{B. Preparation of active investment plans.}

Preparation of operational investment plan is the first premise of can effectively control project investment. In the modern project management, preparation of active investment plan should be:

Not passively according to the established technology design, contract, time limit for a project, implementation plan and the environment, such as project investment budget, but considering the progress of the project, investment, quality and implementation of the mutual influence between and balance, to find the optimal solution.

Investment plans not only limited to the construction cost, project investment should be taken into account after use, operating costs, namely using the project life period cost plan and optimization method preparation of investment plans.

Carried out in accordance with the WBS decomposition structure of bottom-up cost summary, compared with limitation of investment target and plan, to measure the degree of composite plan units, each layer changes a decision to design and plan, forming a bottom-up - added - constant revision control - the control process of feedback

\section{Active control combined with passive control.}

In the process of the implementation of the project investment plan, the combination of active control and passive control should be taken to control method, to ensure smooth implementation of project investment objectives.

\section{1) Active control}

Established in advance investment objectives and investment plan of the project, will respond to environmental uncertainty and risk factors in the engineering construction, etc. Have advanced thinking and forecasting, analysis the influence of various factors on the project investment, predict the possibility of goals and plans in the process of project implementation deviation, adopt corresponding precontrol measures input target and planning system, the active control project implementation.

\section{2) Passive control}

Should also be in the process of the implementation of the project plan to carry on the whole process, the omni-directional monitor, through to the project actual output project information collection, processing, sorting, analysis, timely find problems and find out the deviation, adopt corresponding countermeasures, then feedback to the plan into practice, the administrative department to make engineering problems to be processed on time, make the goals and plans once appear deviation rectified in a timely manner.

3) The combination of active and passive control

\section{Economic visa and engineering control}

$$
\text { measures of the claim }
$$

Supervision should be regularly and timely collect, sort out the relevant construction and supervision of information, visas for the fair and reasonable treatment engineering economy and claim to give evidence.

\section{1) Organization measures of investment} control

Improve the system of division of duties and related, to carry out the responsibility.

On the basis of summarizing the similar project supervision organization powerful supervision team, including construction, material selection, equipment type selection of supervision engineer, have enough strength feasible schedule control network, each division project designated special progress controller is responsible for all aspects of the implementation of progress.

\section{THE INVESTMENT CONTROL METHOD}

\section{A. Investment control in advance}

Investment beforehand control, supervision mechanism on the basis of the construction contract terms, the construction drawing, countermeasures of engineering project cost, the goal for engineering risk prediction, and take the 
corresponding defensive to trace, minimize the contractor may claim.

1)Be familiar with the design drawings and design requirements, pre-tender estimate, bid, contract price factors analysis, clearly the most easy to break part of the project cost and link, so as to clear the focal point of investment control.

2)Prediction project risk and possible claim cause, countermeasure of prevention, reducing the occurrence of the claim against the construction unit.

3)According to the conditions stipulated in the contract, duly submitted to the construction site, make it's can start construction as scheduled, the normal construction, continuous construction, avoid default claim conditions.

4)According to the contract requirements, on schedule, such as the quality, such as to supply the construction unit is responsible for the amount of material and equipment to the site, to avoid the claim is caused due to the default conditions.

5)According to the contract requirements, design drawings and other technical information provided in a timely manner, to avoid the claim is caused owing to the default conditions.

\section{B. Investment matter controls}

1)As stipulated in the contract, reply in a timely manner and to comply with requirements, contractor questions avoid default and further conditions of the claim.

2)During the construction of the initiative to do a good job in design, materials, equipment, construction, installation and other external coordination, coordination, avoid causing the other conditions of the claim.

3)Supervision engineer should at the cost, functional requirements, quality, time limit for a project review, engineering change solutions and announced before the implementation of engineering change and negotiation between the construction unit, contractor engineering change of the price.

4)Strictly for the visa. Involving economic costs to stop slowdown, employment, use mechanical visas, material substitution and pricing, such as a visa, signed by total project supervision engineer the last nuclear rear effectively.
5)As stipulated in the contract, in a timely manner to have measured the engineering measurement.

6)Supervision of contractors as stipulated in the contract, promptly declared quantities, supervision engineer approve progress payment in time, avoid delaying claim is caused due to the default.

7)Improve the system of price information, timely grasp the scope of state pricing and amplitude.

8)Inspect and supervise the contractors to carry out the contract, make its comprehensive performance.

9)Monthly report to the construction unit project investment dynamic situation.

10)On a regular basis, not on a regular basis to analyze project cost overruns, and control the engineering cost break scheme and measures are put forward.

\section{Investment control afterwards}

In this project, when the actual schedule lag, on the basis of analyzing the reasons, put forward the improvement measures, to ensure that the total time limit for a project no breakthrough, involves changes or cost increases, the total duration should negotiate with the owner change in the schedule or cost compensation, schedule adjustment, adjust the corresponding construction, materials, equipment and money supply plan, organization and coordination of new balance.

1)Audit contractors to submit project settlement book.

2)Fair claim processing contractors

\section{CONCLUSION}

Investment objective is one of the three objectives on the engineering project management. Construction project success or not is closely related to the effect of the investment control. In the construction of the project should be special attention to the crucial role of planning and design stage of investment, seize the key link, can get twice the result with half the effort. Establishing the project WBS is also working to improve the quality of project management must, not only need to establish a WBS in the project planning, it also plays a certain scope of work, the action of planning control depth. Project construction should also carry out progressive during the whole process cost management 
thinking, to give full play to the role of investment control, realize the purpose of cost savings, improve the investment benefit.

\section{REFERENCE}

[1] Xiaode Zuo project investment management [M]. Guangzhou: jinan university press, 2014.

[2] Ye Peng.on the effective control of construction project engineering cost [J]. Construction management modernization, 2012.

[3] Kuosheng Lin. Thinking about project cost target process control. Infrastructure optimization, 2010, 26 (2).

[4] Guirong Zhou. Only compiled from. Successful project management. Beijing: China economic publishing house, 2014.

[5] YishengLiu. Construction project management (second edition). Tsinghua university press, Beijing jiaotong university press, 2014.

[6] Wei Wang. Based on the concept of whole process cost management of construction project cost dynamic control research [D]. Kunming university of science and technology, 2008, (9).

[7] HeHuang. Construction project construction cost determination and control [D]. Shenyang university of technology, 2009, (2).

[8] The theory of the investment main body status and the corresponding rights and interests of state-owned enterprises, and dock li chang, "economic fabric. 1997.

[9] "how can enterprise investment decision hoop scientific, water," economic BBS. 2004.

[10] State council on the decision of the investment system reform ", people's publishing house, 2004.

[11] Investment decision-making errors and the countermeasure, DouShiJiang, "economic BBS. 2004.

[12] Real estate investment analysis, Liu Qiuyan, northeast university of finance and economics press, 2014.

[13] Real estate finance and investment, Long Shengping, renmin university of China publishing house, 2002.

[14] Enterprise investment decision-making risk analysis, you-yi li, huazhong university of science and systems engineering, and 2005.3.

[15] "modern investment", patriotic, Shanghai people's publishing house, 2013. 